\title{
Pengenalan basic navigation-dead reckoning bagi mahasiswa dan alumni Teknik Elektro Institut Teknologi Dirgantara Adisutjipto
}

\author{
Lasmadi ${ }^{*}$, Freddy Kurniawan, Sutjianto Sukarno \\ Program Studi Teknik Elektro, Fakultas Teknologi Industri \\ Institut Teknologi Dirgantara Adisutjipto \\ Email Korespondensi: "lasmadi@itda.ac.id
}

Received July 15, 2021; Revised August 24, 2021; Accepted August 25, 2021

\begin{abstract}
Abstrak
Pengetahuan avionik merupakan hal yang sangat diperlukan bagi mahasiswa prodi Teknik Elektro Institut Teknologi Dirgantara Adisutjipto. Bagi mahasiswa yang mendapatkan kurikulum baru, mereka telah dibekali pengetahuan avionik sesuai dengan target. Namun, bagi angkatan dengan kurikulum sebelumnya dan juga alumni, pengetahuan ini belum sepenuhnya didapatkan. Program pengabdian ini bertujuan untuk memberikan pengetahuan avionik Dead reckoning system kepada mahasiswa prodi Teknik Elektro khususnya angkatan 2016 dan sebelumnya serta alumni. Program ini diwujudkan dalam bentuk webinar melalui media zoom selama dua hari yang terbagi dalam 5 sesi penyampaian materi. Materi disajikan dalam bentuk slide presentasi yang disampaikan oleh para dosen prodi Teknik Elektro. Untuk lebih mendesiminasikan pengetahuan, kegiatan ini juga disiarkan melalui kanal youtube agar dapat diikuti oleh semua lapisan masyarakat. Berdasarkan asal peserta yang mengikuti webinar ini, dapat disimpulkan bahwa pelatihan ini telah memenuhi sasaran. Selain itu, berdasarkan jumlah peserta dan respon yang diberikan kegiatan ini dapat memberikan manfaat bagi sebagian besar peserta. Kegiatan serupa dapat diadakan kembali pada waktu mendatang dengan materi yang berbeda dalam lingkup kedirgantaraan.
\end{abstract}

Kata Kunci: avionik; dead-reckoning; navigasi

\begin{abstract}
Avionics knowledge is indispensable for students of the Electrical Engineering study program at the Adisutjipto Aerospace Technology Institute. For students who get the new curriculum, they have been provided with avionics knowledge according to the target. However, this knowledge has not been fully obtained for the 2016 and previous batches and also for Electrical Engineering alumni. This service program aims to provide avionics knowledge of Dead reckoning system to students of the Electrical Engineering study program, especially the 2016 and previous batches as well as alumni. This program has been realized in the form of a webinar through zoom media for two days which is divided into 5 sessions of material delivery. The material is presented in the form of a slide presentation delivered by the lecturers of the Electrical Engineering study program. To further disseminate knowledge, this activity is also broadcast through the YouTube channel so that all levels of society can participate. Based on the origin of the participants who took part in this webinar, it can be concluded that this training has met its objectives. In addition, based on the number of participants and the responses given, this activity can provide benefits for most participants. Similar activities can be held again in the future with different materials in the aerospace scope.
\end{abstract}

Keywords : avionics; dead-reckoning; navigation

\section{PENDAHULUAN}

Pada saat ini, dunia transportasi modern telah berkembang sangat pesat. Pesawat udara merupakan produk transportasi udara untuk membantu manusia ketika melakukan perjalanan yang jauh. Untuk mendukung suatu perjalanan jauh, dibutuhkan pengetahuan navigasi. Navigasi adalah ilmu melakukan perjalanan di darat, diatas laut, maupun di udara, dimana diperlukan pengetahuan tentang tujuan akhir dan kemajuan di sepanjang perjalanan. Navigasi pesawat diperlukan untuk menemukan posisinya di permukaan bumi dan menentukan arah perjalanan. Perkembangan sistem navigasi pesawat diawali dengan penggunaan referensi visual dan basic compas, kemudian dengan bantuan radio ground/satelit dan sistem mandiri (unguided) dengan berbagai teknik dan metode. Menurut Gajjar, dead reckoning adalah proses menghitung posisi saat ini dengan menggunakan posisi referensi yang ditentukan sebelumnya dan memajukan posisi itu berdasarkan kecepatan yang diketahui atau diperkirakan selama waktu dan jalur yang telah berlalu. Meskipun memberikan informasi yang baik tentang posisi, metode ini rentan terhadap kesalahan karena faktor-faktor seperti ketidakakuratan dalam 
estimasi kecepatan atau arah. Beberapa sensor yang digunakan adalah akselerometer dan giroskop untuk integrasi percepatan/kecepatan pada dead reckoning [1].

Dimulai tahun akademik 2019/2020, pendidikan dan pengajaran di Teknik Elektro Institut Teknologi Dirgantara Adisutjipto (ITDA) menggunakan kurikulum 2019. Kurikulum 2019 ini diberlakukan secara penuh mulai mahasiswa baru angkatan 2019. Kurikulum ini disusun berdasar ketentuan pada akreditasi nasional Badan Akreditasi Nasional Perguruan Tinggi (BAN-PT) dan akreditasi internasional IABEE. Pada kurikulum ini, kompetensi lulusan konsentrasi Elektronika Penerbangan ditingkatkan. Beberapa mata kuliah Avionik ditambahkan, dimana target diberlakukannya ini adalah materi Elektronika Penerbangan dan Elektronika Telekomunikasi dapat lebih mudah dan cepat diserap serta mahasiswa dapat menyelesaikan studi tepat waktu dalam 8 (delapan) semester atau bahkan kurang. Disamping itu, ditambahkan lebih banyak materi mata kuliah yang digunakan di dunia kerja. Bagi mahasiswa angkatan 2016 dan sebelumnya, diberlakukan sistem transisi. Oleh karena itu, materi avionik yang mereka dapatkan tidak sebagaimana mahasiswa angkatan 2019 kecuali jika mereka mengambil kembali mata kuliah kurikulum 2019 [2].

Dengan permasalahan tersebut, Himpunan Mahasiswa Teknik Elektro (HMTE) berusaha menjembatani ketimpangan kurikulum antar angkatan dengan mengadakan pelatihan pengenalan dunia avionik. Kegiatan pelatihan ini bertujuan memberikan edukasi pendalaman avionik bagi mahasiswa dan alumni prodi Teknik Elektro ITDA dalam bentuk webinar melalui kegiatan pengabdian kepada masyarakat. Meski secara implisit ditujukan untuk mahasiswa dan alumni ITDA, namun pelatihan yang dilaksanakan secara daring ini dapat diikuti oleh masyarakat umum semua kalangan sehingga pengetahuan tentang avionik dapat disebarluaskan ke masyarakat. Pada saat pandemi Covid-19, kegiatan pengabdian kepada masyarakat dilangsungkan dalam bentuk webinar (daring). Beberapa kegiatan pengabdian kepada masyarakat dalam bentuk pelatihan secara daring untuk berbagai kelompok masyarakat telah banyak dilakukan [3 - 5]. Demikian juga, kegiatan pelatihan penggunaan media pembelajaran daring untuk PAUD dan TK juga telah dilakukan [6]. Hal ini juga mendukung sistem pembelajaran jarak jauh terkait dengan pandemi Covid-19 dimana kegiatan pengabdian masyarakat banyak dilakukan secara virtual [7].

\section{METODE}

\subsection{Persiapan Kegiatan}

Sebelum pelatihan dilaksanakan, tim telah melakukan observasi mengenai metode yang tepat untuk digunakan. Berdasarkan observasi, dengan mempertimbangkan faktor internal maupun eksternal dari kekuatan, kelemahan, peluang dan ancaman, maka pelatihan ini dikemas dalam tema "Pengenalan Dunia Avionik" yang dibagi dalam beberapa sub tema. Materi pelatihan dan deskripsi materi dapat ditunjukkan pada Tabel 1.

Tabel 1. Materi pelatihan dan deskripsi materi

\begin{tabular}{|c|c|c|c|}
\hline Hari, Tanggal & Materi & Prodi & Deskripsi \\
\hline \multirow{3}{*}{$\begin{array}{c}\text { Rabu, } 24 \\
\text { Februari } 2021\end{array}$} & Pengenalan Avionik & Teknik Elektro & $\begin{array}{l}\text { Menyajikan materi instrumen } \\
\text { avionik pada pesawat terbang }\end{array}$ \\
\hline & $\begin{array}{l}\text { Introduction to Dead } \\
\text { Reckoning }\end{array}$ & Teknik Elektro & $\begin{array}{l}\text { Menyajikan materi sistem } \\
\text { navigasi Dead Reckoning System }\end{array}$ \\
\hline & Introduction to AHRS & Teknik Elektro & $\begin{array}{l}\text { Menyajikan materi Attitude \& } \\
\text { Heading Reference System }\end{array}$ \\
\hline \multirow{2}{*}{$\begin{array}{c}\text { Kamis, } 25 \\
\text { Februari } 2021\end{array}$} & Pengenalan Autopilot & D3 Aeronautika & $\begin{array}{l}\text { Menyajikan materi autopilot } \\
\text { system pada pesawat terbang }\end{array}$ \\
\hline & Teknik Kendali Digital & Teknik Elektro & $\begin{array}{l}\text { Menyajikan materi teknik kendali } \\
\text { digital }\end{array}$ \\
\hline
\end{tabular}

Kemudian, melihat situasi dan kondisi, penyampaian materi avionik disampaikan dengan bentuk webinar dan materi bisa dinikmati seluruh lapisan masyarakat kapan saja dan di mana saja. Demikian juga, untuk menyebarluaskan pengetahuan pada siswa sekolah menengah, tim telah mengundang para siswa SMA/K Penerbangan untuk mengikuti pelatihan ini.

\subsection{Waktu dan Tempat Penyelenggaraan Kegiatan}

Perencanaan kegiatan pelatihan ini telah dirancang sebelumnya dan dikomunikasikan dengan berbagai pihak. Kegiatan pelatihan ini dilaksanakan pada tanggal 24 sampai 25 Februari 2021 secara daring melalui media zoom dan disiarkan secara live melalui kanal youtube. Lokasi penyelenggaraan kegiatan pengabdian kepada masyarakat berada di kampus Institut Teknologi Dirgantara Adisutjipto Yogyakarta yang ditunjukkan pada peta sebagaimana Gambar 1 . 


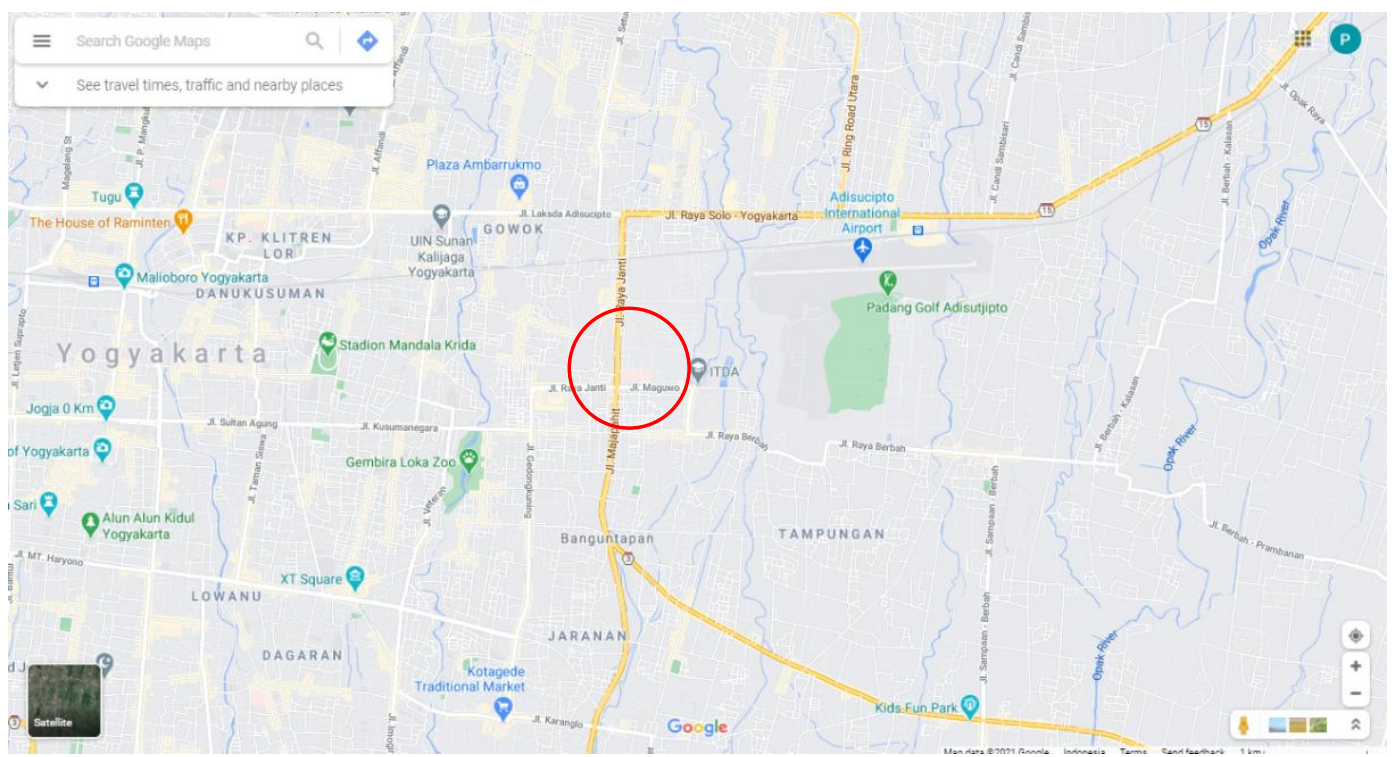

Gambar 1. Peta lokasi penyelenggaraan kegiatan.

\subsection{Pelaksanaan Kegiatan}

Kegiatan pada hari pertama dimulai pukul 09.00 WIB dengan pembukaan oleh master of ceremony (MC). Kemudian, dilanjutkan dengan sambutan oleh Kepala LPPM ITDA. Setelah itu, pemaparan materi sebagaimana Tabel 1 dengan dipandu oleh seorang moderator. Materi pertama kegiatan ini disampaikan Pengenalan Avionik oleh bapak Sutjianto S. Materi ini menyajikan sistem instrumen avionik pada pesawat terbang yang berisi: Pengertian dan fungsi sistem avionik di pesawat terbang, Aircraft Communication System, Aircraft Electricity System, Airborne Collision Avoidance System, Flight control systems, Flight Management systems, Engine Indicating and Crew Alert System (EICAS), Engine and Flight System Monitoring, Navigation System, Attitude Direction Indicator (ADI), Electronic Attitude Direction Indicator (ADI), Horizontal Situation Indicator (HSI), Electronic Horizontal Situation Indicator (EHSI), dan Instrument Landing System (ILS). Materi tentang instrumen tersebut diteruskan dengan teknologi tampilan di cockpit yang meliputi pengenalan: Glass Cockpit, Primary Flight Display and Navigation Display, HUD Technology.

Kemudian, sesi kedua dilanjutkan dengan materi Pengenalan Dead Reckoning System oleh bapak Lasmadi yang berisi tentang: pentingnya navigasi, metode-metode navigasi, dead reckoning system, dead reckoning applications, metode wind triangle, Inertial Navigation Systems (INS), dan inertial navigation principles. Materi disajikan melalui tampilan slide presentasi yang bisa disaksikan oleh semua peserta pelatihan. Contoh sederhana diberikan untuk memudahkan memahami materi. Selain itu, dijelaskan aplikasi metode ini pada pesawat terbang dan UAV (unmanned aerial vehicles). Kegiatan pelatihan ini sebagian besar dilakukan dengan interaksi langsung bersama para peserta. Dengan bantuan berbagai pihak termasuk bagian staf Teknologi Informasi dan mahasiswa, kegiatan ini dapat terlaksana dengan baik. Untuk menyebarluaskan pengetahuan tentang avionik ini kepada masyarakat luas, kegiatan ini juga ditayangkan di kanal official youtube ITDA. Sebagian tayangan slide di sesi materi Dead Reckoning dalam zoom dapat dilihat pada Gambar 2.
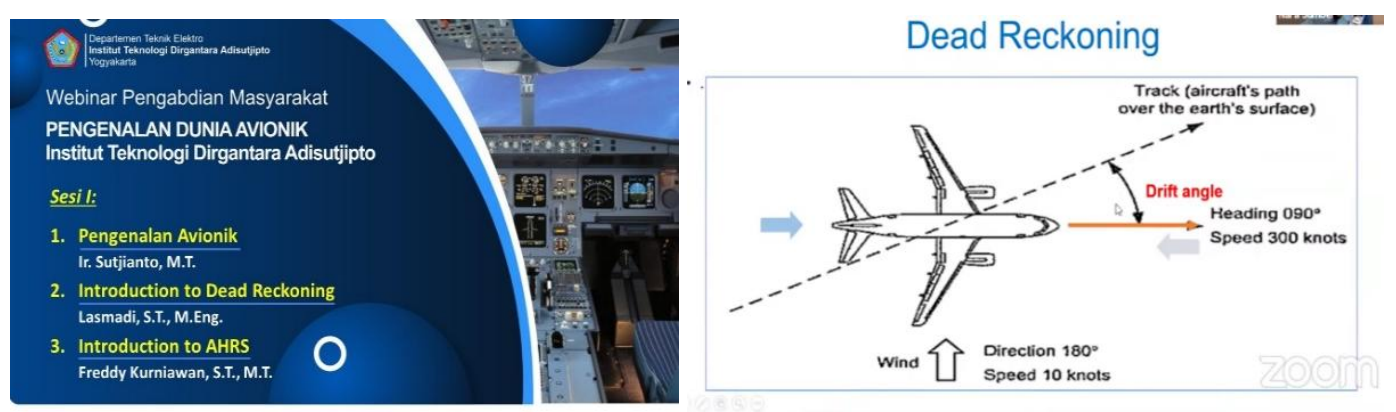

Gambar 2. Sebagian tampilan slide materi tentang dead reckoning dalam zoom

Sesi selanjutnya diberikan penjelasan tentang Attitude and Heading Reference System oleh bapak Freddy K. Materi ini berisi: Pengertian dan fungsi Attitude and Heading Reference System (AHRS), komponen AHRS, 
Penentuan attitude dan heading, penggabungan data sensor akselerometer, magnetometer dan giroskop dengan Kalman filter.

Sebagian materi ini merupakan hasil penelitian dosen dengan mahasiswa ITDA [8 - 11]. Oleh karena itu, pemberian materi avionik ini juga merupakan salah satu upaya diseminasi hasil penelitian kepada masyarakat.

\subsection{Evaluasi Kegiatan}

Proses evaluasi dilakukan dengan membagikan kuesioner kepada para peserta terkait dengan proses pelatihan yang telah dilaksanakan. Hasil kuesioner tersebut kemudian diolah untuk mengetahui penilaian peserta terhadap pelatihan yang telah dilaksanakan.

\section{HASIL DAN PEMBAHASAN}

\subsection{Peserta Pengabdian}

Kegiatan pelatihan avionik bagi mahasiswa dan alumni ITDA ini diikuti oleh sekitar 191 peserta dengan latar belakang asal/instansi peserta meliputi: ITDA, Unsurya dan universitas selainnya, alumni ITDA, SMA/K Penerbangan, Lapan dan peserta Umum seperti ditunjukkan dalam diagram Gambar 3.

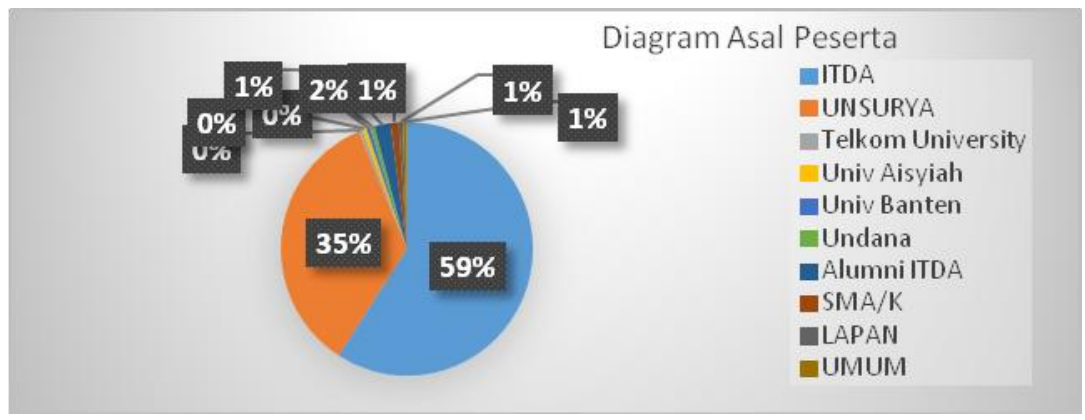

Gambar 3. Data asal peserta

Seperti dapat dilihat dalam diagram Gambar 3, sebanyak 59\% atau sebanyak 114 peserta berasal dari ITDA dan sebanyak 35\% atau sebanyak 67 peserta berasal dari Unsurya. Kemudian, untuk peserta tingkat universitas selainnya kurang dari 1\%. Peserta dari kalangan alumni sebesar 2\% atau sebanyak 4 peserta, sementara peserta dari Lapan, tingkat SMA/K dan peserta umum kurang dari 1\%. Dari data ini menunjukkan bahwa peserta dari kalangan mahasiswa yang berasal dari ITDA mempunyai minat paling tinggi, disusul peserta dari Universitas Dirgantara Marsekal Suryadarma (Unsurya). Hal ini mungkin terkait dengan materi kegiatan yang bercirikan dirgantara, sesuai dengan latar belakang pendidikan peserta. Selain itu, dengan penghargaan berupa sertifikat dimungkinkan dapat mendorong motivasi peserta dari kalangan mahasiswa. Peserta dari kalangan siswa SMA/K penerbangan masih sedikit dimungkinkan karena materi belum/tidak sesuai dengan kurikulum tingkat sekolah menengah. Selain itu, bisa dimungkinkan karena keterbatasan waktu sosialisasi terhadap calon peserta di tingkat sekolah menengah. Tampilan screenshoot sebagian peserta kegiatan webinar dalam zoom ditunjukkan dalam Gambar 4.
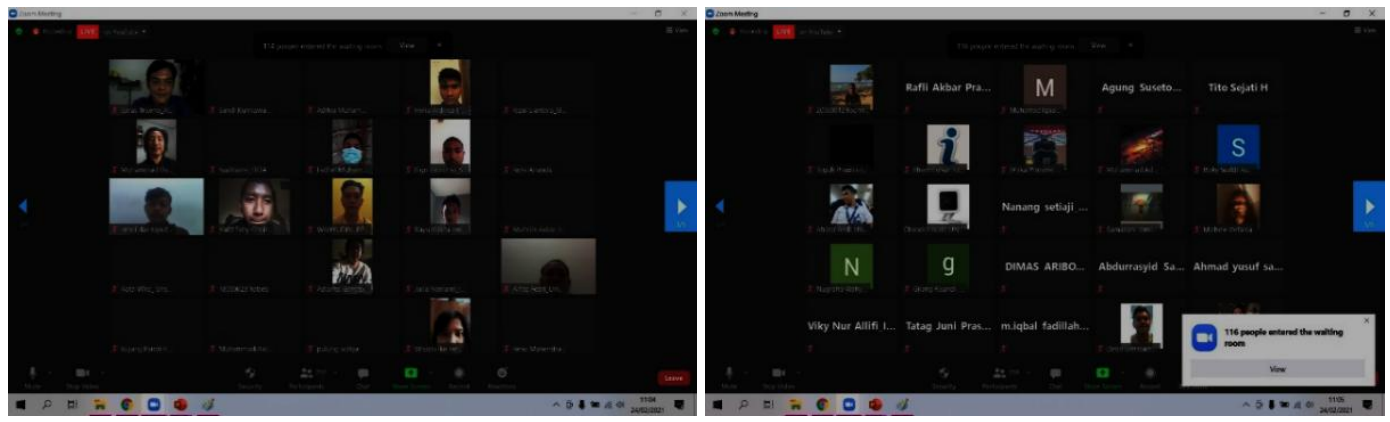

Gambar 4. Screenshoot sebagian peserta kegiatan webinar dalam zoom

\subsection{Evaluasi Kegiatan}

Setelah kegiatan pelatihan dilaksanakan, tim kegiatan juga menggunakan WhatsApp maupun email untuk berbagi materi dalam bentuk soft file dan memberikan sertifikat kepada peserta. Selain itu, tim pengabdian membagikan tautan Google Form untuk mengevalusi kegiatan. Dalam form tersebut peserta diminta untuk memberikan respon dengan menjawab beberapa pertanyaan sebagaimana ditunjukkan pada Gambar $5-7$. 


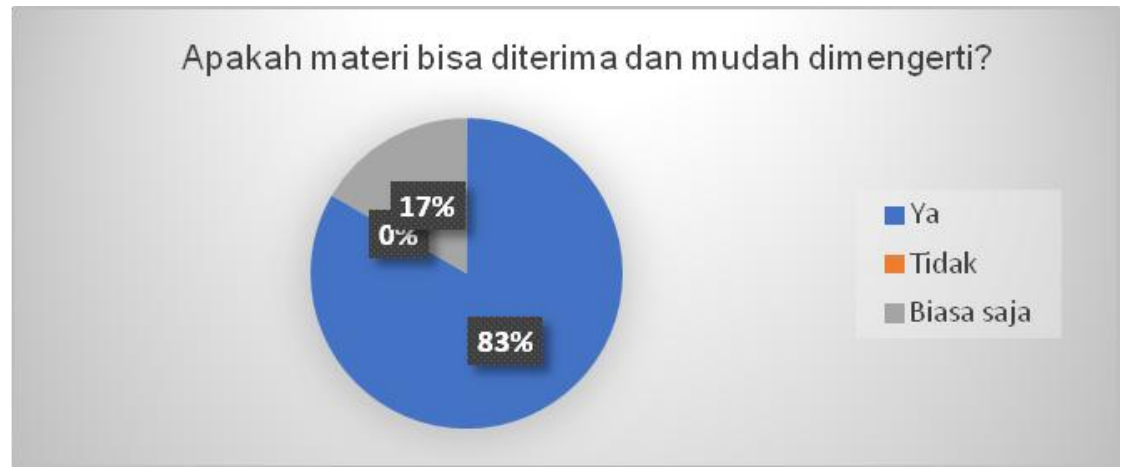

Gambar 5. Respon peserta tentang pemahaman materi kegiatan webinar avionic

Dari diagram Gambar 5, sebanyak 83\% responden merasa mudah memahami materi kegiatan webinar; sementara sebanyak $17 \%$ menjawab biasa saja dan tidak kesulitan memahami materi. Dari prosentase ini, sebagain besar peserta dapat memahami materi yang disampaikan oleh narasumber meskipun ada sebagian peserta menganggap biasa saja. Hal ini bisa dimaklumi karena latar belakang peserta yang berbeda baik dari sisi pemahaman maupun tingkat pendidikan. Bagi responden yang memberikan pendapat biasa saja, bukan berarti tidak memahami materi yang disampaikan. Hal ini dapat disintesis dari grafik bahwa tidak ada responden yang samasekali tidak memahami materi yang disampaikan atau sebesar 0\%. Dari sini dapat disimpulkan, materi dapat tersampaikan dengan baik meskipun melalui media daring dan sebagian peserta dapat menerima materi yang disampaikan.

Pada saat acara berlangsung, sebagian peserta juga mengajukan pertanyaan kepada narasumber yang menunjukkan perhatian mereka terhadap materi yang disampaikan. Evaluasi selanjutnya adalah tentang kepuasan jawaban narasumebr terhadap pertanyaan peserta. Terhadap jawaban narasumber, responden memberikan pendapat sebagimana diagram yang ditunjukkan pada Gambar 6.

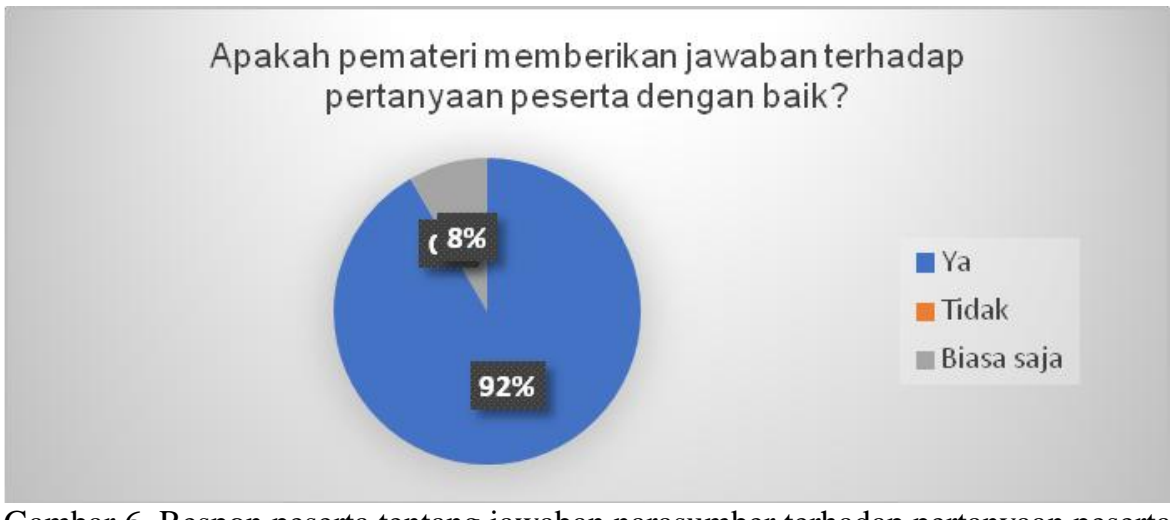

Gambar 6. Respon peserta tentang jawaban narasumber terhadap pertanyaan peserta

Dari diagram Gambar 6, sebagian besar responden yaitu sebesar 92\% merasa puas dengan jawaban narasumber, sementara sebagian sisanya menganggap biasa saja. Dalam menjawab pertanyaan peserta, dibutuhkan latar belakang pengetahuan pemateri yang cukup. Sehingga, berdasarkan hasil ini, pengetahuan pemateri atau penyaji masih perlu ditingkatkan lagi untuk kegiatan-kegiatan sejenis pada kesempatan selanjutnya.

Mengenai pertanyaan tentang materi webinar selanjutnya, dari beberapa opsi materi yang ditawarkan, responden terlihat antusias memberikan jawaban sebagaimana ditunjukkan pada Gambar 7. Materi yang ditawarkan untuk webinar selanjutnya tentang Keselamatan penerbangan, Avionik lanjut, dan Dasar bagaimana pesawat dapat terbang. Dari opsi materi-materi ini, Sebagian besar responden memilih materi dasar bagaimana pesawat terbang dapat mengudara. Hal ini menunjukkan bahwa pengetahuan dasar tentang Avionik masih sangat diperlukan oleh kebanyakan masyarakat. Sehingga, untuk kegiatan sejenis selanjutnya, penekanan tentang materi dasar penerbangan perlu menjadi perhatian. Dari diagram Gambar 7 terlihat bahwa masyarakat masih memerlukan tentang pengetahuan dasar dunia penerbangan, sehingga kegiatan pengabdian kepada masyarakat tentang pengenalan dunia penerbangan dan avionik dalam bentuk webinar bisa diadakan pada waktu mendatang. 


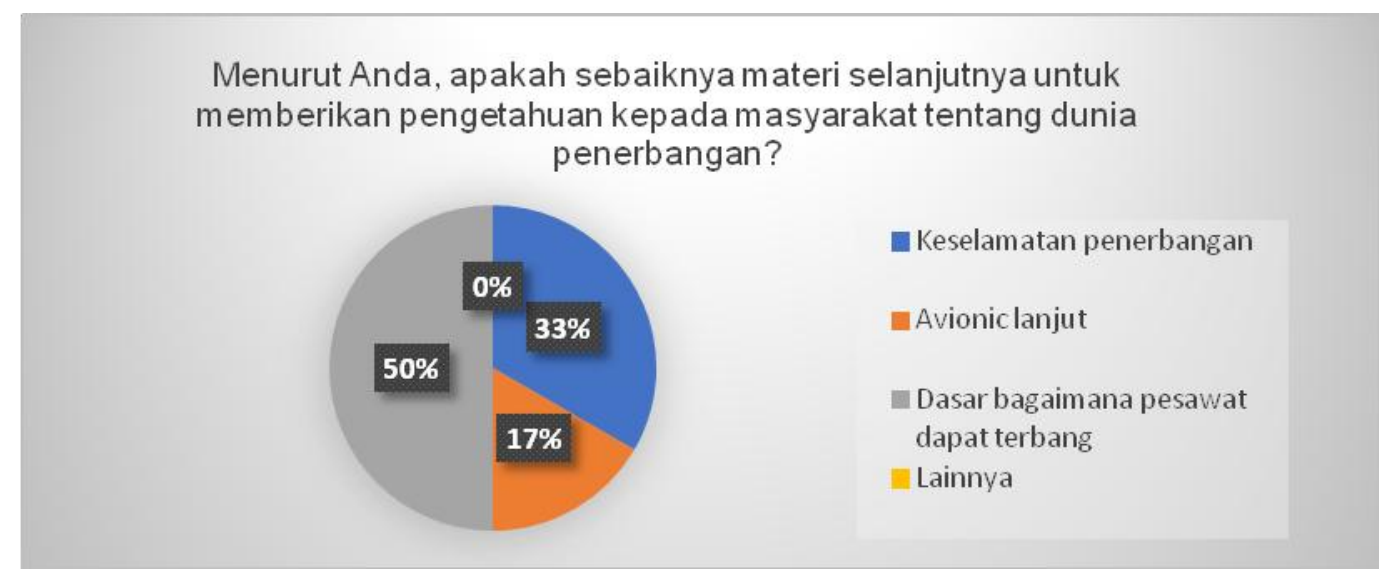

Gambar 7. Respon peserta tentang tema kegiatan webinar selanjutnya.

\section{KESIMPULAN}

Berdasarkan jumlah peserta yang mengikuti kegiatan ini, masyarakat cukup antusias untuk mengikuti kegiatan ini. Dari latar belakang asal peserta yang mengikuti webinar ini, dapat disimpulkan bahwa kegiatan pengabdian pada masyarakat ini telah memenuhi tujuan dan sasaran yang diharapkan. Selain itu, berdasarkan respon peserta kegiatan ini dapat memberikan manfaat pada sebagian besar peserta terhadap materi yang diberikan. Kegiatan serupa dapat diadakan kembali pada waktu mendatang dengan materi yang berbeda khususnya untuk para pemerhati dan pecinta dunia kedirgantaraan.

\section{DAFTAR PUSTAKA}

[1] Gajjar, Manish J, “Mobile Sensors and Context-Aware Computing,” Morgan Kaufmann. 2017.

[2] F. Kurniawan, Lasmadi, and S. Sukarno, "Pengenalan Attitude Heading Reference System bagi Himpunan Mahasiswa dan Alumni Prodi Teknik Elektro Institut Teknologi Dirgantara Adisutjipto," KACANEGARA Jurnal Pengabdian pada Masyarakat, vol. 4, no. 2, pp. 143-150, Jul. 2021.

[3] L. Iswati, "Pelatihan TOEFL secara virtual bagi anggota Nasyiatul "Aisyiah Cabang Mantrijeron Yogyakarta", KACANEGARA Jurnal Pengabdian pada Masyarakat, vol. 4, no. 2, pp. 247-254, Jul. 2021.

[4] A. Solichin, D. Kristanto, and G. Triyono, "Optimasi pembelajaran daring siswa dan guru di masa pandemi Covid-19 menggunakan Google Classroom pada PKBM Bhakti Asih," KACANEGARA Jurnal Pengabdian pada Masyarakat, vol. 4, no. 2, pp. 239 - 246, Jul. 2021.

[5] Nico, W. Wahyudin, and I. L. Hilmi, "Edukasi terhadap masyarakat terkait mitigasi Coronavirus Disease (COVID-19) di Kabupaten Karawang," KACANEGARA Jurnal Pengabdian pada Masyarakat, vol. 4, no. 2, pp. 173-180, Jul. 2021.

[6] Suryani, Vera, Bayu Erfianto, and Andrian Rakhmatsyah. "Pemberdayaan guru paud RA Al-Ghifari Sukabirus Dayeuhkolot dalam penyusunan bahan ajar berbasis online," KACANEGARA Jurnal Pengabdian pada Masyarakat, vol. 4, no. 2, pp. 189-194, Juli 2021.

[7] Musi, Muhammad Akil, and Parwoto Parwoto. "Pelatihan Pengembangan Program Kemitraan PAUD Di Tengah Pandemi Covid-19." PENGABDI, vol. 1, no. 2, 2020.

[8] L. Lasmadi, A.I. Cahyadi, S. Herdjunanto, R. Hidayat, "Inertial Navigation for Quadrotor Using Kalman Filter with Drift Compensation," International Journal of Electrical and Computer Engineering (IJECE), vol. 7, no. 5, pp. 25962604, 2017.

[9] MAR. Wicaksono, F. Kurniawan, L. Lasmadi, "Kalman Filter untuk Mengurangi Derau Sensor Accelerometer pada IMU Guna Estimasi Jarak," AVITEC, vol. 2, no. 2, 2019.

[10] Briyan Yoga Sandi, Freddy Kurniawan, L. Lasmadi, "Estimasi sudut orientasi rigid body dengan menggunakan sensor IMU (Inertial Measurement Unit) dan Magnetometer," in SENATIK, Yogyakarta, 2020.

[11] Lasmadi, L., Kurniawan, F., Pamungkas, M. I., "Estimasi Sudut Rotasi Benda Kaku Berbasis IMU Menggunakan Kalman Filter," AVITEC, vol. 3, no. 1, pp. 57-68, 2021. 